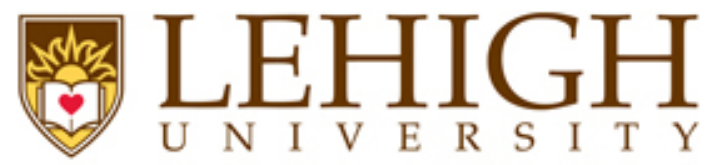

ARIEL
UNIVERSITY
PRESS

Archaeology and Text: A Journal for the Integration of Material Culture with Written Documents in the Ancient Mediterranean and Near East

Vol. 1, 2017 
Archaeology and Text: A Journal for the Integration of Material Culture with Written Documents in the Ancient Mediterranean and Near East

\section{Editors}

David Small, Lehigh University.Email dbs6@lehigh.edu

Itzhaq Shai, Ariel University.Email: shai.itzick@gmail.com 


\section{Editorial Board:}

Yonatan Adler, Department of Land of Israel Studies and Archaeology, Ariel University

Colleen Darnell, Department of Art History, University of Hartford

Thomas Gallant, Department of History, University of California at San Diego

Onno van Nijf, Department of History, University of Groningen

Robin Osborne, Faculty of Classics, Cambridge University

James Whitley, School of History, Archaeology, and Religion, Cardiff University

K. Lawson Younger, Jr., Department of Old Testament and Semitic Languages, Trinity International University 


\section{Table of Contents}

Divination Texts of Maresha - Archeology and Texts

Esther Eshel, Bar Ilan University, Ian Stern, Archaeological Seminars Institute

Toward an "Archaeology of Halakhah": Prospects and Pitfalls of

Reading Early Jewish Ritual Law into the Ancient Material Record

Yontan Adler, Ariel University

27

Purity Observance among Diaspora Jews in the Roman World

Jodi Magness, University of North Carolina at Chapel Hill

Visual Models in Archaeology and Harmonization of Archaeological

and Literary Data Catalin Pavel, Kennesaw State University

Reading Between the Lines: Jewish Mortuary Practices in Text and Archaeology Karen B. Stern, City University of New York, Brooklyn College

Complex Purity: Between Continuity and Diversity in Ancient Judaism 


\section{Editorial Statement}

The study of the human past has conventionally been divided between two distinct academic disciplines depending upon the kind of evidence under investigation: "history", with its focus on written records, and "archaeology", which analyzes the remains of material culture. This new annual publication, Archaeology and Text: A Journal for the Integration of Material Culture with Written Documents in the Ancient Mediterranean and Near East, aims to bridge this disciplinary divide by providing an international forum for scholarly discussions which integrate the studies of material culture with written documents. Interdisciplinary by nature, the journal offers a platform for professional historians and archaeologists alike to critically investigate points of confluence and divergence between the textual and the artifactual.

We seek contributions from scholars working in the ancient Mediterranean and Near East. Contributions with a theoretical or methodological focus on the interface between archaeology and text are especially encouraged. By publishing all of its articles online, the Archaeology and Text seeks to disseminate its published papers immediately after peer-review and editorial processes have been completed, providing timely publication and convenient access.

In providing a forum, we will publish reviews of recent publications which deal with the issue of archaeology and text. When appropriate, each volume will include a short overview of recent conferences which have treated this topic as well. 


\section{Recent Conferences focused on the Issue of Archaeology and Texts}

Archaeology and Text: Toward Establishing a Meaningful Dialogue between Written Sources and Material Finds

Conference held on Sunday May 10 - Monday May 11, 2015. Sponsored by Ariel University and the Israel Ministry of Science, Technology, and Space. Conference was organized into several small sessions. Papers ranged from those dealing with the issue of archaeology and texts in the Near East to those focusing on this issue in Mediterranean Studies. Topics ranged from the application of textual material to singular sites - Text and Archaeology: the Case of Tel Rehov in the 10-9 $9^{\text {th }}$ Centuries BCE, A. Mazar - to more theoretical contributions - Purity and Purification in the Dead Sea Scrolls and the Mikva'ot of Qumran: the Convergence of Archaeology and Text, L. Schiffman.

Textual Archaeology of Ancient Near East: Are We Doing it Wrong?

Conference held on Thursday December 10 - Sunday December 13, 2015. Sponsored by the McDonald Institute for Archaeological Research, Cambridge University. Conference was subdivided into various sessions with invited responses. Topics focused on issues pertaining to the Near East with a few inclusions of cases dealing with the Bronze Age Aegean. Papers ranged from those treating the issues of the uses of archaeology and texts in broad areas in the Near East, such as Assyriology - Of Haematite and Apricots: Matching up the Mesopotamian World, N. Postgate - to contributions touching upon landscape - Satellite Remote Sensing, Archaeological Survey, and Historical Geography in Northern Mesopotamia, J. Casana - the analysis of texts in ancient Mayan studies - Histories of Decline and Fall: Archaeology, Epigraphy, and the Maya Collapse, N. Carter.

The Conference is being published by the McDonald Institute, with its organizer, Y. Heffron as the editor. 


\title{
Toward an "Archaeology of Halakhah": Prospects and Pitfalls of Reading Early Jewish Ritual Law into the Ancient Material Record
}

\author{
Yontan Adler, Ariel University
}

\begin{abstract}
Archaeology is indispensable for understanding the genesis and development of halakhah, Jewish ritual law, and the impact of its observance on the functioning of ancient Jewish societies. Using examples from my own work over the past few years, this paper seeks to illustrate the kinds of data archaeology can provide on how ancient halakhah was practiced, information which is simply not to be found in texts. The topics to be surveyed include mikva'ot (ritual baths), chalkstone vessels, and tefillin (phylacteries). The unique contribution of archaeology to the study of each of these halakhic phenomena is explored, with a special focus on what archaeology has to teach us about these rituals which we would not have known from the texts alone. Some of the potential hazards and pitfalls of using archaeology together with texts of a halakhic nature are discussed as well, including the anachronistic use of written sources in interpreting earlier remains and the mistaken privileging of rabbinic halakhah over alternative possibilities. Archaeology and texts tend to provide very different kinds of information, and if brought together prudently, hold the potential to offer a much more comprehensive and accurate understanding of how halakhah was observed in the ancient past.
\end{abstract}

\section{Introduction}

"Halakhah", in its broadest sense, refers to the overall system of Jewish law, especially as this relates to the details of ritual practice. Although the term first appears in Late Roman period rabbinic literature (see: Meier 2003), today the term "halakhah" is used in scholarship to refer to systems of Jewish ritual law which are not necessarily rabbinic, and so we may speak of "Pharisaic halakhah", "Sadduceean halakhah", "Qumranic halakhah", and so on. Here I will be using the term in this most expansive 
sense in referring to any Jewish approach to the practical implementation of Torah law. Chronologically, it is quite difficult to speak of any sort of halakhah prior to the composition and widespread reception of the Pentateuch, and as such our discussion below will focus on the historical era beginning with the latter half of the Second Temple period through Late Antiquity (i.e. the late Hellenistic, Roman, and Byzantine periods in Palestine).

The observance of halakhah played a central role in the day-to-day lives of Jews throughout extended periods of Jewish history. The tenacious commitment of Jews to their ancestral laws even to the point of martyrdom is a theme found repeatedly among ancient authors, Jewish and non-Jewish alike (see, e.g., Rajak 1997). In his widelycited article on halakhah in the Dead Sea Scrolls, Yaakov Sussmann famously argued that the proper observance of ritual law was of such vital concern to Jews living in the late Second Temple era, that the rise of the various sects at this time owes itself first and foremost to differences in interpretation of halakhah, and that it was halakhah - as opposed to theology - around which the various sects circled their wagons (Sussmann 1990: 61-64).

Recognizing the critical significance of halakhah for the development of Judaism and for the unfolding of Jewish history, scholarship beginning with the $19^{\text {th }}$ century Wissenschaft des Judentums movement has made great strides in developing a "history of halakhah", an investigation of how various aspects of halakhah originated and developed over time. Unfortunately, this vitally important field of inquiry has focused its efforts almost exclusively on the evidence provided by written sources, mostly late Second Temple period Jewish literature and early rabbinic texts. Material evidence provided by archaeology was unavailable to the earlier researchers, and mostly ignored by later ones. Here I will argue that archaeology is in fact indispensable for understanding the genesis and development of halakhah, and for appreciating the impact of ritual law and its observance on the functioning of ancient Jewish societies. ${ }^{1}$ Using examples from my own work over the past few years, I will try to illustrate the kinds of data archaeology can provide on how ancient halakhah was practiced, information of the sort which is simply not to be found in texts. I will conclude my presentation with a few words of caution relating to the hazards and pitfalls inherent in

\footnotetext{
${ }^{1}$ The recently published volume (based on a 2011 conference held at Yeshiva University) dedicated to the use of archaeology in understanding rabbinic materials (Fine and Koller 2014) is an excellent example of how archaeology can be utilized to explicate early rabbinic literary sources, both halakhic and aggadic. See especially: Meyers 2014; Sperber 2014. The present essay focuses specifically on the use of archaeology for understanding halakhic practices, and how these developed over time and space regardless of whether or not these practices were rooted in the rabbinic sphere.
} 
such a venture. In this way, I believe, what I call here an "Archaeology of Halakhah" may serve as a felicitous case study of a field in which a meaningful dialogue between written sources and material finds might be sought.

\section{Prospects}

Admittedly, archaeological investigation is possible for only a limited range of halakhic questions. As a ready example, the very first law discussed in the Mishnah relates to the question of when the Shema' liturgy is to be recited in the evening: "מאימתי קוראין את שמע בערבין (m. Berakhot 1:1). Clearly, recitation of liturgies, prayers, and benedictions is something which cannot be expected to leave any traces in the archaeological record. This is of course true of a large number of practices governed by halakhah, which are of a completely non-material nature. This having been said, there are numerous halakhic practices which in one way or another involve materiality and which therefore can be studied through the lens of archaeology. Salient examples include: synagogue architecture, restrictions on idolatry and figural art, mezuzot and their placement on doorposts, the four species ritual on Sukkot, and the dietary laws as reflected in archaeozoological remains. In the present paper I will focus on three additional topics which have been particularly important in my own recent work: mikva'ot (ritual baths), chalkstone vessels, and tefillin (phylacteries). I will focus here on the unique contribution of archaeology to the study of each of these halakhic phenomena, and what archaeology has to teach us about these rituals which we would not have known from the texts alone.

\section{Mikva'ot}

Mikva'ot (singular: mikveh) are pools used for the ritual immersion of impure persons, utensils, and clothing, as described in early rabbinic literature, especially in tractate Mikva'ot in both the Mishnah and the Tosefta, rabbinic works thought to have been redacted around the $3^{\text {rd }}$ century C.E. Beginning with Yigael Yadin's excavations at Masada in 1963-65 (see: Yadin 1966: 164-67), archaeologists have uncovered increasing numbers of stepped water installations which conventionally have come to be identified as mikva'ot. Over 850 such installations are known today, which date from circa 100 B.C.E. until the end of the Byzantine period in Palaestina, circa the middle of the seventh century C.E. (Adler 2011a: 319-343). 
The question of why stepped water installations should be identified as ritual purification pools is in and of itself an excellent exercise in the use of archaeology together with texts (Adler 2011a: 33-42; Reich 2013: 46-52; Miller 2015: 32-55). What I would like to focus on here, however, is the question of what archaeology can teach us about Jewish ritual purification practices which we did not already know from a study of the written sources by themselves.

Without archaeology, we would have had no idea that in the late Second Temple period Jews were immersing in artificial, purposely built installations designed for ritual immersion. Although the subject of purity, purification, and ritual immersion appears not infrequently in Second Temple period literature, incredibly enough, nowhere in the writings which have come down to us from this period is any mention made of where ritual immersions actually took place. It is exclusively the archaeological finds which teach us that by the first century B.C.E., Jews were immersing themselves in artificial stepped pools.

Something else which we would never really know for sure is how widespread the practice of ritual immersion was among the Jewish population of Judea at large. True enough, ritual purity was an important issue in much of Second Temple period Jewish literature. Ritual washing and immersion are topics discussed not infrequently in these sources. The problem is that, like all texts, these literary sources reflect the subjective viewpoints of their authors, and we can never really know for sure how representative these viewpoints may have been of the non-literary (and probably even non-literate) common folk living in Judea at the time. We know, for example, that the authors of various texts found at Qumran took great interest in things having to do with ritual purity. Philo, Josephus, the New Testament authors, and the later rabbis all tell us about ways that different individuals and groups observed the purity laws, including ritual washings. What is extremely difficult to learn from these sources, however, is to what extent these practices might have been observed by regular common folk on a dayto-day basis. Whereas texts tend to highlight the fringes of society, whether literary elites or religious pietists, archaeology is exceptionally well-suited for shedding light on precisely those who make up the majority of society but whose voices often go silent in the texts. The fact that numerous mikva'ot tend to be found at any given Early Roman period settlement site, no matter how small, strongly indicates that the Jewish populace at large made regular use of these purification pools (Adler 2014a: 70).

Archaeology also allows us to investigate possible discrepancies in the distribution of these installations between various regions, and provides us for the first time with hard data which may point to differences between, for example, Judea in the south 
and Galilee in the north - a question with great ramifications for the study of the nascent Jesus movement (Adler 2011a: 293-300). Careful study of the material finds also allows us to track the use of mikva'ot over time, pinpointing when they first appeared, when the phenomenon peaked, and at what point in time did the use of these installations eventually wane (Adler 2011a: 50-68; Adler 2017b).

\section{Chalkstone Vessels}

Chalkstone vessels are another archaeological phenomenon from this era associated with ritual purity observance. During the Early Roman period, various types of vessels made of chalkstone, serving as both domestic tableware and storage containers for food and liquids, were in widespread use at Jewish sites throughout Judea, Galilee, and Perea, supplementing the usual repertoire of ceramic vessels (Cahill 1992; Deines 1993; Magen 2002; Adler 2011a: 161-220). This was a uniquely Jewish phenomenon, as remains of chalkstone vessels are conspicuously absent from non-Jewish sites. Why is the distribution of these vessels so clearly divided along these ethnic-religious lines? Scholarship has conventionally answered this question by interpreting the archeological finds in light of texts. The Tannaitic rabbis assume that stone vessels cannot contract ritual impurity and, as such, never have need for purification (e.g. Sifre, Huqat 126 [ed. Kahana, 411-12]). Vessels made of stone were used on various occasions when the ritual purity of a vessel was to be ensured (e.g., m. Beșah 2:3; m. Parah 3:2,11). This practice appears to underlie the Gospel of John's explanation that the stone water jars featuring in the wedding at Cana narrative were associated with "the purity (laws) of the Jews" (John 2:6 lit.). Interpreting the archaeological chalkstone vessels in light of these texts, scholars have explained that Jews produced and used these vessels specifically because of their unique quality of imperviousness to ritual impurity (Deines 1993: 166-246; Magen 2002: 138-47; Adler 2011a: 178-82; cf. Miller 2015: 153-183). As a result, chalkstone vessel remains are conventionally interpreted as an indication of ritual purity observance.

While the later rabbinic sources lay the theoretical basis for our understanding that at least some Jews in ancient times believed that stone was a material impervious to impurity, nowhere in the rabbinic literature do we find any clue that Jews everywhere throughout the country were producing and using tableware and storage vessels fashioned from stone on a regular, probably daily basis. Once again, it is archaeology, and archaeology alone, which allows us to recognize how widespread this phenomenon was among rank-and-file Jews throughout the country, regardless of socioeconomic 
or sectarian differences, and hence how central ritual purity concerns were for Jews throughout Early Roman Judea. And again, it is only through archaeology that we can the trace the development of chalkstone vessel use over historic time and through geographic space. One fascinating result of this archaeological investigation has been the recognition that chalkstone vessels remained in widespread use for decades after the destruction of the Jerusalem Temple in 70 C.E., a discovery which seems to indicate that the observance of purity laws in general may have had very little to do with the Temple cult and much more with concerns over personal piety (see Adler 2017b).

\section{Tefillin}

The final example we shall explore of how archaeology provides a significant contribution to the study of ancient halakhah is that of tefillin. In discussing tefillin, we are actually referring to artifacts composed of two distinct components: (1) leather cases, intended to house (2) rolled-up slips made of thin skins inscribed with biblical texts. These leather cases, holding their inscribed slips, would have been worn on the head and arm (or hand) of the tefillin practitioner.

Because both components of tefillin are made of organic material, all ancient tefillin remains known today derive exclusively from caves in the Judean Desert where the arid environmental conditions preserved the ancient skins. Altogether, twenty-three leather tefillin cases were found at Qumran, all of which presumably predate 70 C.E., and an additional two cases were found in refuge caves dating to the end of the Bar Kokhba revolt, around 135 C.E. (for a survey on the distribution of these finds, see: Adler 2017a). Aside from these cases, 34 decipherable slips have also been found, again mostly from Qumran, with a minor number found in Bar Kokhba period refuge caves as well (ibid).

Considering the small quantity of tefillin remains uncovered and the extremely limited scope of their find-spots, it is impossible to produce any meaningful distribution map for tefillin. Unlike what we saw above with regard to mikva'ot and chalkstone vessels, there is really no way of knowing to what extent the Judean Desert tefillin finds might be representative of general practices throughout the country. Similarly, we cannot investigate differences between geographic regions, nor are we on firm ground for investigating significant chronological developments. Nevertheless, the tefillin finds do provide us with invaluable information about this ritual practice which we never would have known from the written sources alone. The only ancient texts we have which describe the tefillin ritual in any detail are rabbinic, and it is very 
hard to learn from these sources what non-rabbinic or pre-rabbinic tefillin practice might have looked like. The archaeological finds provide a first view into the way the ritual was performed in lived reality by those who were presumably situated outside the sway of rabbinic influence. ${ }^{2}$ We learn from these finds, for example, that while some Jews included in their tefillin the exact same Pentateuchal pericopae as described by the rabbis, others included these and additional texts, for example, the Decalogue (see: Adler 2011b: 224-228). Variety in practice can also be noted with regard to the morphology of the tefillin cases: some are shaped as a solid pouch divided into 4 individual cells, while others have these cells separated by slits (Adler 2017a: 164-66). These and other discrepancies between the individual tefillin exemplars may represent chronological, or more likely sectarian differences, within Early Roman period Jewish practice - differences never openly discussed in the literature of the later rabbis (ibid).

\section{Potential Pitfalls}

In my call for developing an "Archaeology of Halakhah", it is not enough to point out the prospects - it is also necessary to point out some of the potential pitfalls of using archaeology together with texts of a halakhic nature.

One extremely common mistake is to read the material finds exclusively through the prism of rabbinic halakhah. Here I have in mind those scholars who proverbially hold the spade in one hand and the Mishnah in the other. Many such scholars assume, as a matter of course, that the ancient individuals responsible for the archaeological remains necessarily followed rabbinic prescriptions. The rationale behind such an approach is clear: nowhere do we find a more detailed and intricate treatment of early halakhah than in rabbinic literature. It is far easier to assume that the material finds represent a halakhic tradition about which we know a great deal, than to grope in the dark with halakhic approaches about which we know very little. The problem with reading the rabbinic rulings into the archaeological finds is two-fold. The first problem is that the earliest works of rabbinic literature were redacted into their final form no earlier than the beginning of the $3^{\text {rd }}$ century C.E., and while these writings are thought to contain earlier traditions, it is no simple task to discern and date the various strata found within them. Clearly it would be a gross error to interpret archaeological remains in light of halakhic concepts which came into being only a century or two later.

\footnotetext{
${ }^{2}$ For a recent monograph which utilizes archaeological finds together with textual sources in order to postulate an apotropaic function for tefillin, see: Cohn 2008.
} 
The second problem relates to the question of rabbinic influence. It is thought that during the first centuries of the Common Era, no more than a few dozen rabbis would have been active in Roman Palestine at any given time (Levine 1989: 66-69; Lapin 2012: 65-67). To what extent these rabbis and their halakhic ideas had any influence at all over other Jews during this time is not really known. It is completely unwarranted to simply assume that everyone living at the time of the rabbis would have abided by their halakhic rulings, or would even have been aware of what these rulings may have been.

A glaring example of this kind of naïve approach to the use of rabbinic sources in interpreting archaeological finds may be found in the latest volume of the Masada final reports, where an entire chapter, replete with detailed diagrams, is dedicated to harmonizing the $1^{\text {st }}$ century B.C.E. and $1^{\text {st }}$ century C.E. archaeological remains of stepped pools at Masada with the significantly later rabbinic sources (Grossberg 2007). Even if the archaeological remains and the texts had been contemporaneous, it would be completely unjustified to simply assume that the people who built and used these (or any other) pools both knew and seriously cared anything about what the rabbis had to say.

Anachronisms aren't limited to using Late Roman rabbinic halakhah to elucidate earlier archaeological finds. Even more serious is when archaeological finds are interpreted in light of medieval or even modern Jewish practices. We may cite examples where chalkstone mugs are interpreted as washing cups (Deines 1993: 23133, 245-46; Magen 2002: 99), ${ }^{3}$ chalkstone bowls are interpreted as havdalah spice boxes (Berlin 2006: 150), and mikva'ot in Hasmonean and Roman period Judea are interpreted in light of practices which first appeared in 18th or 19th century Europe (for a critique of this very popular anachronistic interpretation, see: Adler 2014b).

An important recent corrective to these mistaken approaches can be found in Stuart Miller's recent volume on ritual purity (Miller 2015). Throughout the book, Miller postulates that scholars have been offering a completely wrong view of the issue, and suggested that rabbinic halakhah be seen as a somewhat natural development deriving from the actual practices evidenced in the material culture, as opposed to the other way around. That is, while rabbinic halakhah took for granted earlier practices, the rabbis went one step further by taking the halakhic questions at hand in new directions. As Miller rightly asserted, such an appreciation of the rabbinic project provides all the more reason to avoid imposing the views of the rabbis on the archaeological finds.

\footnotetext{
${ }^{3}$ For a previous critique of this interpretation, see: Miller 2015: 176.
} 


\section{Conclusions}

I have tried to make the case for a study of ancient Jewish ritual law which makes discriminating use of archaeology in conjunction with halakhic texts. Archaeology and texts tend to provide very different kinds of information, and if brought together prudently, hold the potential of offering a much more comprehensive and accurate understanding of how halakhah was observed in the ancient past. Many of the potential prospects and pitfalls that I have pointed out for this "Archaeology of Halakhah" are no doubt applicable in other fields, where texts may be studied profitably in tandem with material culture.

The past is long gone. We will never again be able to experience the past. We will never even be able to gaze upon the past as upon some panoramic view. The wall of time stands in the way, completely blocking our field of vision. Snippets of evidence, whether textual or archaeological, act as small apertures in this wall, providing the most restricted of glimpses. If we are prudent enough to peer through all of the available peepholes, and wise enough to recognize that each vantage point provides a very different perspective on the same grand scene, we will at least begin to appreciate in some modest but meaningful way that past we so desperately seek beyond the barrier of time. 


\section{List of References}

Adler, Y.

2011a

The Archaeology of Purity:

Archaeological Evidence for the

Observance of Ritual Purity in

Erez-Israel from the Hasmonean

Period until the End of the Talmudic

Era (164 BCE-400 CE). Ph.D.

dissertation, Bar-Ilan University

(in Hebrew).

$2011 b$

The Context and Order of the Scriptural Passages in Tefillin:

A Reexamination of the Early Rabbinic Sources in Light of the Evidence from the Judaean Desert, Pp. 205-229 in Halakhah in Light of Epigraphy, eds. A.I. Baumgarten, H. Eshel, R. Katzoff, and S. Tzoref. Journal of Ancient Judaism Supplement 3. Gottingen: Vandenhoeck and Ruprecht.

$2014 a$

'Come and See the Extent to Which Purity Had Spread' (T. Shab 1.14): An Archaeological Perspective on the Historical Background to a Late Tannaitic Passage, Pp. 6382 in Talmuda de-Eretz Israel: Archaeology and the Rabbis in Late Antique Palestine, eds. S. Fine and A. Koller. Studia Judaica 73. Berlin: de Gruyter.
$2014 b$

The Myth of the 'Ôșār' in Second Temple Period Ritual Baths: An Anachronistic Interpretation of a Modern-Era Innovation. Journal of Jewish Studies 65: 263-83.

$2017 \mathrm{a}$

The Distribution of Tefillin Finds among the Judean Desert Caves, Pp. 161-173 in The History of the Caves of Qumran: Proceedings of the International Conference, Lugano 2014, ed. M. Fidanzio. Studies on the Texts of the Desert of Judah 118. Leiden: Brill.

$2017 b$

The Decline of Jewish Ritual Purity Observance in Roman Palaestina: An Archaeological Perspective on Chronology and Historical Context, Pp. 269-284 in Expressions of Cult in the Southern Levant in the GrecoRoman Period. Manifestations in Text and Material Culture, eds. O. Tal and Z. Weiss, Contextualizing the Sacred Series 6. Turnhout: Brepols.

Berlin, A.M.

2006

Gamla I: The Pottery of the Second Temple Period: The Shmarya 
Gutmann Excavations, $1976-$ 1989. Isarel Antiquities Authority Reports no. 29. Jerusalem: Israel Antiquities Authority.

Cahill, J.

1992

Chalk Vessel Assemblages of the Persian/ Hellenistic and Early Roman Periods, Pp. 190-274 in Excavations at the City of David 1978-1985: Directed by Yigal Shiloh, vol. III, Stratigraphical, Environmental, and Other Reports, eds. A. De Groot and D.T. Ariel, Qedem 33. Jerusalem: Institute of Archaeology, Hebrew University of Jerusalem.

Cohn, Y. B.

2008

Tangled Up in Text: Tefillin and the Ancient World. Providence: Brown University Press.

Deines, R.

1993

Jüdische Steingefässe und pharisäische Frömmigkeit: Ein archäologisch historischer Beitrag zum Verständnis von Joh 2,6 und der jüdischen Reinheitshalacha zur Zeit Jesu. Wissenschaftliche Untersuchungen zum Neuen Testament. Reihe 2, 52. Tübingen: Mohr.
Fine, S., and Koller, A., eds.

2014

Talmuda de-Eretz Israel: Archaeology and the Rabbis in Late Antique Palestine. Studia Judaica 73. Berlin: De Gruyter.

Grossberg, A.

2007

The Miqva'ot (Ritual Baths) at Masada, Pp. 95-126 in Masada, vol. VIII: The Yigael Yadin Excavations 1963-1965: Final Reports, eds. J. Aviram et al. Jerusalem: Israel Exploration Society and The Hebrew University of Jerusalem.

Lapin, $\mathrm{H}$.

2012

Rabbis as Romans: The Rabbinic Movement in Palestine, 100-400 C.E. Oxford: Oxford University Press.

Levine, L. I.

1989

The Rabbinic Class of Roman Palestine in Late Antiquity. Jerusalem and New York: Yad Izhak Ben-Zvi and The Jewish Theological Seminary of America.

Magen, Y.

2002

The Stone Vessel Industry in the Second Temple Period: Excavations at Hizma and the Jerusalem 
Temple Mount, Judea and Samaria Publications 1. Jerusalem: Israel Exploration Society.

Meier, J. P.

2003

Is there 'Halaka' (The Noun) at Qumran?" Journal of Biblical Literature 122: 150-155.

Meyers, E.

2014

The Use of Archaeology in Understanding Rabbinic Materials: An Archaeological Perspective, Pp. 303-319 in Talmuda de-Eretz Israel: Archaeology and the Rabbis in Late Antique Palestine, eds. S. Fine and A. Koller. Studia Judaica 73. Berlin: De Gruyter.

Miller, S. S.

2015

At the Intersection of Texts and Material Finds: Stepped Pools, Stone Vessels, and Ritual Purity Among the Jews of Roman Galilee. Journal of Ancient Judaism Supplements 16. Göttingen: Vandenhoeck \& Ruprecht.

Rajak, T.

1997

Dying for the Law: The Martyr's Portrait in Jewish-Greek Literature, Pp. 39-67 in Portraits: Biographical Representation in the
Greek and Latin Literature of the Roman Empire, eds. M. J. Edwards and S. Swain. Oxford: Clarendon.

Reich, R.

2013

Miqwa'ot (Jewish Ritual Baths) in the Second Temple, Mishnaic and Talmudic Periods. Jerusalem: Yad Izhak Ben-Zvi and Israel Exploration Society (in Hebrew).

Sperber, D.

2014

The Use of Archaeology in Understanding Rabbinic Materials: A Talmudic Perspective, Pp. 321346 in Talmuda de-Eretz Israel: Archaeology and the Rabbis in Late Antique Palestine, eds. S. Fine and A. Koller. Studia Judaica 73. Berlin: De Gruyter.

Sussmann, Y.

1990

The History of Halakha and the Dead Sea Scrolls: Preliminary Observations on Miqșat Ma'ase Ha-Torah (4QMMT). Tarbiz 59: 11-76 (in Hebrew).

Yadin, Y. 1996

Masada: Herod's Fortress and the Zealots' Last Stand. London: Weidenfeld and Nicolson. 